\title{
Impact of land-use land cover dynamics on runoff in Panchnoi River basin, North East India
}

\author{
Monoj Kumar Jaiswal ${ }^{1 \otimes}-$ Nurul Amin $^{2}$ \\ ${ }^{1}$ Centre for Studies in Geography, Dibrugarh University, Dibrugarh, India \\ ${ }^{2}$ Department of Geology, Jagannath Barooah College, Jorhat, India \\ $\bowtie$ mkumar_ias@yahoo.co.in
}

\begin{abstract}
Alteration of land-use land cover pattern causes severe consequences on the hydrological system by modifying the rainfall-runoff pattern in a region. The study aimed to investigate the impact of land-use land-cover dynamics on runoff generation in different geomorphic divisions of Panchnoi River basin. The study used the Soil Conservation Service-Curve Number method to estimate runoff generation in the Panchnoi River basin in a GIS platform. This study observed that the conversion of the land-use pattern in the geomorphic zones significantly enhances runoff. The Piedmont experience highest land-use change, where $64.17 \mathrm{~km}^{2}$ forest cover lost to cropland and built-up lands, leads to a notable increase in runoff generation, i.e. from $1076 \mathrm{~mm}$ (52.82\% of rainfall) in 1990 to 1467 $\mathrm{mm}$ (70.46\% of rainfall) in 2015. The Flood plain and New alluvial plain generates high runoff in the basin as it mostly occupied by human-induced land-uses, i.e. $1444 \mathrm{~mm}$ (72.72\% of rainfall) and $1360 \mathrm{~mm}(71.70 \%$ of rainfall) respectively in 1990, which increase to $1588 \mathrm{~mm}(79.20 \%)$ and $1507 \mathrm{~mm}$ (78.69\%) runoff respectively in 2015, due to alteration of cropland to built-up lands. In the Old alluvial plain, a marginal land-use change observed resulted in moderate growth in runoff from $1272 \mathrm{~mm}$ (62.35\%) to 1404 $\mathrm{mm}(66.79 \%)$. The study indicates land-use land-cover change invokes to increase runoff generation can give rise severe environmental and economic problems in the river basin, through the occurrence of flashflood and soil erosion.
\end{abstract}

\section{Highlights for public administration, management and planning:}

- Evaluation of the impact of land-use land cover dynamics on runoff is essential for containing flash flood and water resource management on a basin scale.

- Alteration of natural land covers has severe implications in the form of flood, soil erosion, and loss of biodiversity.

- Enhanced runoff due to land-use dynamics reduces groundwater recharge rate that may cause drinking water scarcity in the dry season shortly.

\section{Introduction}

The estimation and evaluation of the availability of water resources are essential for regional planning and sustainable development (Russo et al. 2014; Loucks \& Beek 2017). Human Societies depends on the availability of freshwater, not only to fulfil the domestic needs but to achieve economic prosperity also; it plays a crucial role in most human creations ( Cosgrove \& Loucks 2015). However, this precious gift of nature is becoming

\section{Keywords}

Geographic information system (GIS),

Geomorphic zones,

Land use land cover

(LULC),

Runoff,

Soil conservation

Service-Curve Number (SCS-CN)

\section{Received:}

03 July 2020

Received in revised form: 15 January 2021

Accepted:

16 March 2021 scarce due to human actions (Venkatesh \& Ramesh 2018) that needs to conserve through management (Ningaraju et al. 2016). Land-use and land cover (LULC) dynamics is a crucial factor to modify surface runoff and water availability at the basin scale (Yin et al. 2017). The study of the effects of LULC dynamics on the availability of water resource becomes a core issue in recent years (Samie et al. 2019).

LULC is one of the significant factors influencing regional hydrological characteristics, and its alteration leads to change in water distribution pat- 
tern and hydrological processes such as evaporation, runoff, lateral flow, infiltration, and groundwater ( $\mathrm{Li}$ et al. 2018). The impact of LULC change on runoff generation is a complicated phenomenon, depends on several factors such as the size of the watershed, average slope, soil texture, and baseline LULC characteristics (Petchprayoon et al. 2010; Zare et al. 2016). The humaninduced LULC change, especially through the development of croplands and built-up lands considerably affects hydrological processes (Hibbert 1967; Bosch $\&$ Hewlett 1982) and enhances runoff generation (Garg et al. 2018). The conversion of LULC usually has an unintended consequence on the natural environment (Regmi et al. 2017; Jaiswal \& Amin 2020), especially in the form of enhanced runoff and soil erosion (Guzhaet et al. 2018; Ma et al. 2018; Messele \& Moti 2019). Several studies conducted to envisage the role of LULC pattern on hydrological processes since the mid of the last century (Dwarakish \& Ganasri 2015; Zhang et al. 2016) and many empirical and mathematical models developed for estimating hydrological processes, especially the surface runoff (Hjelmfelt 1991; Mishra \& Singh 2003; Uwizeyimana et al. 2018; Matomela et al. 2019). This study focuses on the effects of LULC change in the surface runoff scenario of the Panchnoi river basin. Here, the prime concern was to evaluate the role of different land-use categories on runoff scenarios with particular stress to LULC dynamics and runoff generation. The findings of this research can help land managers and decision-makers to formulate strategies to tackle the on-site, and offsite damages arise due to excessive surface runoff caused by LULC dynamics.

\section{Materials and methods}

The study conducted in the Panchnoi river basin, located in the western foothill region of Arunachal Himalaya in India, is an essential sub-basin of the Brahmaputra. The river basin extended from $26^{\circ} 33^{\prime} 13^{\prime \prime} \mathrm{N}$ to $27^{\circ} 04^{\prime} 29^{\prime \prime} \mathrm{N}$ latitudes and $92^{\circ} 15^{\prime} 14^{\prime \prime}$ $\mathrm{E}$ to $92^{\circ} 24^{\prime} 01^{\prime \prime} \mathrm{E}$ longitude (Fig. 1) with an area of $552.4 \mathrm{~km}^{2}$; out of which $150.36 \mathrm{~km}^{2}$ are in Arunachal Pradesh and the rest in Assam. The Panchnoi river originates in Arunachal Himalayan ranges at an elevation of $2920 \mathrm{~m}$ above mean sea level (MSL) and flows at a length of 75.05 $\mathrm{km}$ to meet the Brahmaputra River, with the general surface slope towards the south (Jaiswal \& Amin 2020). The basin has diverse geological composition ranging from Quaternary sediments (southern plains), Siwalik sediments, rocks of the lower Gond- wana group, and metasediments of the Bomdila group (northern hills) (Geological Survey of India [GSI], 2009, 2010). The basin has characteristics of high seismicity, flimsy geological base, seasonal weather variations, assorted physiography, rich biodiversity (Jaiswal et al. 2014). The basin experiences sub-tropical humid climate characterised by the southwest monsoon rhythm. The annual precipitation of the river basin is assorted one, and about $70 \%$ of rainfall occurs in the monsoon months (June-September), mostly in the form of a torrential downpour (Jaiswal \& Amin, 2020). The Panchnoi River basin covered with several natural vegetation types that include sub-alpine forests, meadows with coniferous and tropical evergreen trees, sub-tropical semi-evergreen trees and mixed deciduous trees (Jaiswal 2013).

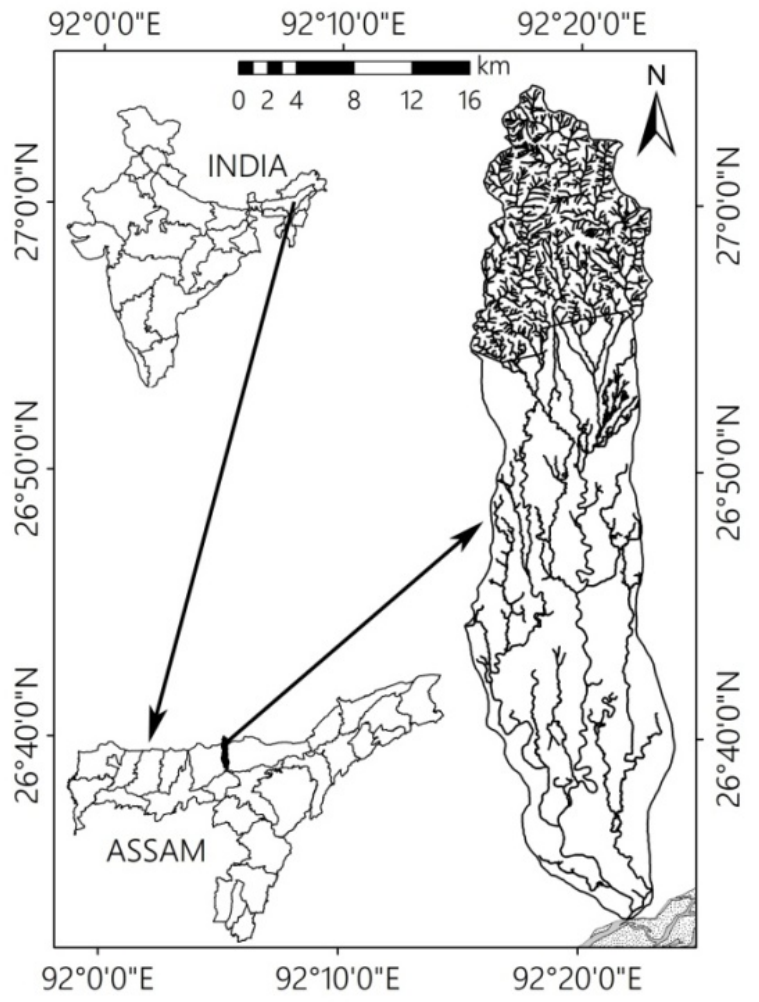

Fig. 1 Geographic location of the study area in Panchnoi River Basin

The present study used the Soil Conservation Service- Curve Number (SCS-CN) model (United States Department of Agriculture [USDA], 1964, 1972 , 2004) to estimate the runoff depth under different LULC set up for the periods of 1990, 2000, and 2015. SCS-CN technique is one of the primogenital and most straightforward methods for runoff modelling (Satheesh Kumar et al., 
Table 1 Details of various data used in the present study

\begin{tabular}{|c|c|c|c|}
\hline Type of data & Year & Author/Source & Title \\
\hline Toposheets & 1972 & Survey of India (SOI) & $83-\mathrm{A} / 8, \mathrm{~B} / 5$, and $\mathrm{B} / 6(1: 50000)$ \\
\hline Rainfall Data & $1990-2015$ & $\begin{array}{l}\text { India Meteorological Department and } \\
\text { Water resource department (Govt. of Assam) }\end{array}$ & Daily rainfall data \\
\hline Thematic maps & 1999 & $\begin{array}{l}\text { National Bureau of Soil Survey and Land-Use } \\
\text { Planning (NBSS and LUP), Nagpur }\end{array}$ & $\begin{array}{l}\text { Soil map of Assam and } \\
\text { Arunachal Pradesh }\end{array}$ \\
\hline Topography Data & 2014 & $\begin{array}{l}\text { United States Geological Survey, } \\
\text { EarthExplorer' website }\end{array}$ & $\begin{array}{l}\text { Shuttle radar topographic mission } \\
\text { (SRTM) } 30 \mathrm{~m} \text { resolution DEM }\end{array}$ \\
\hline Remote Sensing data & 1990, 2000, 2015 & $\begin{array}{l}\text { United States Geological } \\
\text { Survey, EarthExplorer' website }\end{array}$ & $\begin{array}{l}\text { LANDSAT TM, } \\
\text { LANDSAT ETM }\end{array}$ \\
\hline Hydrological data & $1990-2015$ & $\begin{array}{l}\text { Water resource department } \\
\text { (Govt. of Assam) }\end{array}$ & Daily discharge data \\
\hline
\end{tabular}

2017) in a GIS platform, hence extensively used worldwide (Zelelew 2017; Odiji et al. 2020), as well as in India (Ningaraju et al. 2016; Sutradhar 2018; Huda 2019). To evaluate the impact of LULC change on runoff generation in different geomorphic zones in the Panchnoi River basin, necessary data from authentic government sources have used. The different sets of data used for the study with their sources given in Table 1.

\subsection{Image interpretation and LULC classification}

Landsat TM, Landsat ETM images of 1990, 2000, and 2015 was co-registered and geometrically rectified through the SOI toposheets (scale 1 : 50 000). The image was correlated, checked, and verified with the distinct, identifiable objects on the ground; field surveys also conducted to check ground realities. The study has followed the National Remote Sensing Agency (NRSA) LULC classification system (NRSA 2006) to classify the LULC pattern in the river basin. Further, the study used on-screen digitisation method where LULC classes were identified through visual image interpretation based on the following elements like tone, texture, size, shape, pattern, and association (Anderson et al. 1976) in ESRI ArcGIS 9.3 version software. Following NRSA classification the study has identified nine major LULC classes; these are (1) cropland, (2) built-up land, (3) dense forest, (4) scrub forest, (5) tea plantation, (6) grasslands, (7) sand bars, (8) rivers, and (9) wetlands.

\subsection{Identification and delineation of geomorphic divisions}

The study area is endowed with diverse geomorphic settings ranging from lofty Himalayan Moun- tains in the north to riparian flood plain in the south, and other features in between. Delineation of geomorphic divisions was made through the analysis of satellite imageries, soil map, digital elevation model (DEM) of the river basin, and field observations (Bishop et al. 2012). The study reveals the Panchnoi River basin has six major geomorphic divisions; these are (i) Hills, (ii) Denudational hills, (iii) Piedmont, (iv) New Alluvial plains, (v) Old Alluvial plains, and (v) Flood plain, as shown in Fig. 2.

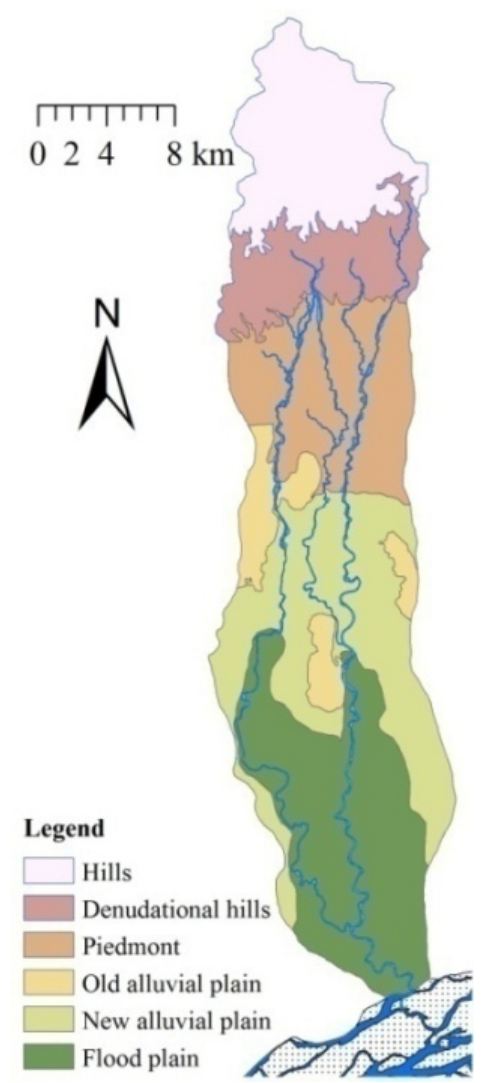

Fig. 2 Geomorphic divisions of the Panchnoi River basin 


\section{sciendo}

\subsection{Hydrological method: SCS-CN approach for runoff calculations}

The SCS-CN runoff equation developed to estimate total storm runoff from total storm rainfall. In the SCS-CN runoff equation, the ratio of the amount of actual retention to watershed storage assumed to be equal to the rate of actual direct runoff to the adequate rainfall (total rainfall minus initial abstraction). The relationship in mathematical form as given by Soil Conservation Service of the United States Department of Agriculture, using Equation 1 (Mishra \& Singh 2003; Khare \& Kundu 2017).

$$
\frac{F}{S}=\frac{Q}{(P-I a)}
$$

Where, $\mathrm{F}=$ actual retention $(\mathrm{mm}) ; \mathrm{S}=$ watershed storage or retention $(\mathrm{mm}) ; \mathrm{Q}=$ actual direct runoff $(\mathrm{mm}) ; \mathrm{P}=$ total rainfall $(\mathrm{mm}) ;$ Ia $=$ initial $\mathrm{ab}$ straction $(\mathrm{mm})$. The total precipitation is the sum of runoff, initial abstraction losses and infiltration losses. The runoff depth then estimated from the relationship provided in Equation 2.

$$
Q=\left(\frac{(P-I a)^{2}}{P-I a+S}\right)
$$

Eliminating the necessity of estimating both parameters $I a$ and $S$ in the above equation, the relation between $I a$ and $S$ was developed by analysing rainfallrunoff data for many small watersheds (USDA, 1986). Ia was assumed to be a function of the maximum potential retention, $S$. An empirical relationship between $I a$ and $S$ expressed as Equation 3.

$$
I a=0.2 S
$$

The rainfall-runoff relationship is obtained by substituting Equation 2 for initial abstraction using Equation 4.

$$
Q=\left(\frac{(P-0.2 S)^{2}}{P+0.8 S}\right)(p \geq 0.2 S)
$$

$\mathrm{S}$ is the retention parameter varies spatially due to changes in soils characteristics, LULC pattern, slope, and management practices; besides these $\mathrm{S}$ also varies temporarily due to changes in soil water content. The retention parameter defined as Equation 5.

$$
S=\frac{25400}{C N}-254
$$

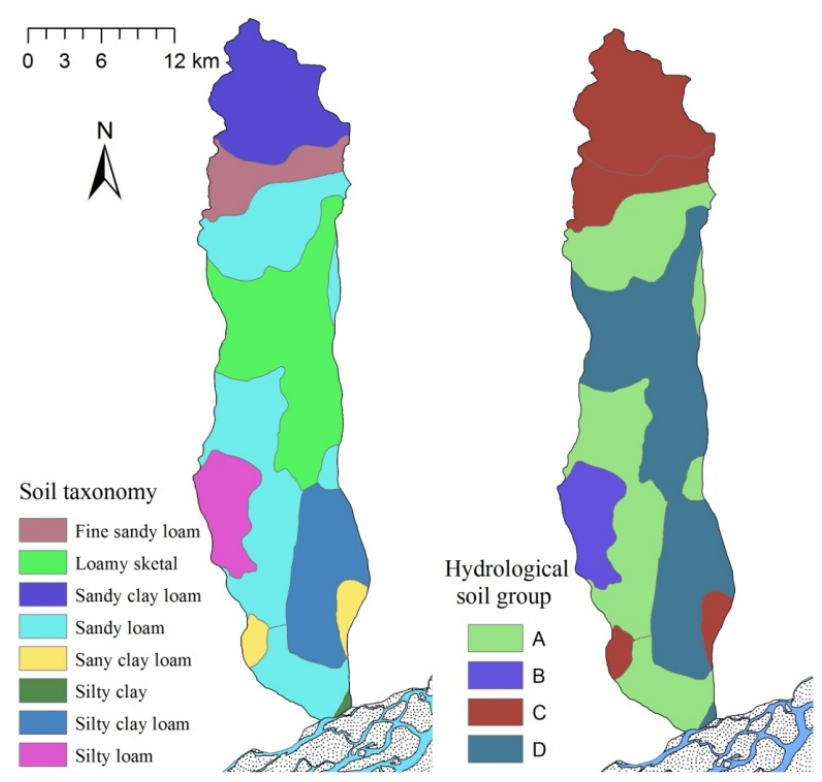

Fig. 3 Soil taxonomy and hydrological soil groups of the Panchnoi River basin

The $C N$ is the dimensionless number ranging from $0-100$, determined from a table, based on LULC and Hydrological soil group (HSG) according to Antecedent moisture condition (AMC) of the soil group (Tailor and Shrimali, 2016). Based on water infiltration rate of the soil, HSG classified into four groups (A, B, C, D) (Table 2). Whereas, AMC refers to the soil wetness and moisture content present in the soil before a rainfall storm event under consideration (Askar 2014). AMC expressed in three

Table 2 USDA hydrological soil classification (USDA, 1972)

\begin{tabular}{lllll}
\hline HSG & Characteristics & Runoff potential & Water transmission & Final Infiltration \\
\hline Group A & $\begin{array}{l}\text { Deep, well-drained sands and gravels } \\
\text { Group B }\end{array}$ & Low & High rate & $>7.5$ \\
& $\begin{array}{l}\text { Moderately deep, well-drained } \\
\text { with moderately fine to coarse texture }\end{array}$ & Moderate & Moderate rate & $3.8-7.5$ \\
Group C & $\begin{array}{l}\text { Clay loams, shallow sandy loam, } \\
\text { soils with moderate to fine texture }\end{array}$ & Moderate & Moderate rate & $1.3-3.8$ \\
Group D & Clay soils that swell significantly when wet & High & Low rate & $<1.3$ \\
\hline
\end{tabular}


levels (I, II and III), according to moisture condition in soil, AMC I (dry) for low moisture content, AMC II standard moisture content, and AMC III (wet) high moisture content (Rawat \& Singh 2017).
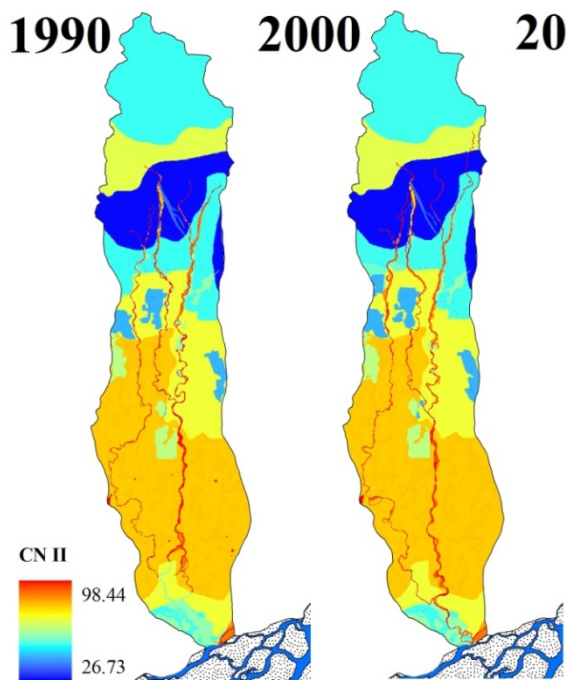

2015

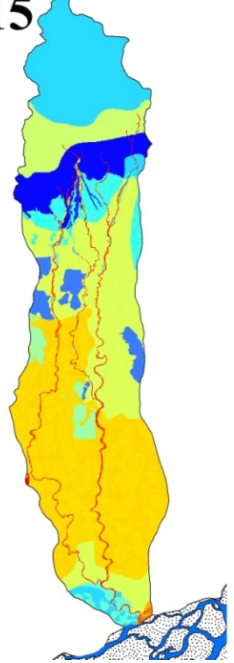

Fig. 4 CNIIs of the Panchnoi River basin for 1990, 2000, and 2015

The hydrological soil groups of the study area prepared according to soil taxonomy of the study area. Soil map data of the region collected from National bureau of soil survey and land use planning (NBSS\&LUP) and prepared HSG map for the study area (Fig. 3) along with soil taxonomy classes of the river basin.

The CN values of each LULC categories, according to HSG, are documented (Table 3) for the case of AMC II called CNII (USDA, 1986). These CNII values are reliable only up to $5 \%$ slope regions, but in natural conditions, some parts of a watershed have more slopes therefore to overcome this problem slope adjusted $C N$ II formulated as Eq. 6 (Sharpley \& Williams 1976).

$$
\text { CNIIs }=\frac{1}{3}(\text { CNIII }- \text { CNII })\left(1-2 \exp ^{-13.86 \text { slope }}\right)+\text { CNII }
$$

Using the above mentioned Equation 6 CNIIs of the Panchnoi River basin prepared for the years 1990, 2000, and 2015, and found that due change in land-use pattern CNIIs of the basin constantly changes in different parts of the basin (Fig. 4). The slope adjusted curve number CNIIs found by using equation 6 on the CNII map of LULC categories and hydrologic soil group in the GIS environment. CNIs and CNIIIs calculated by use of Equations 7 and 8 (Chow et al. 1988).

$$
\text { CNIs }=\frac{4.2 \text { CNIIs }}{10-0.058 \text { CNIIs }}
$$

$$
\text { CNIIIs }=\frac{23 \text { CNIIs }}{10+0.13 \text { CNIIS }}
$$

Where, CNIs and CNIIIs are slope adjusted curve numbers for AMC-I (dry) and AMC-III (wet) conditions, respectively. The value of $\mathrm{CN}$ would range from 0 to 100 .

Table 3 Curve number values for each LULC categories in specific HSGs of AMC II

\begin{tabular}{lllll}
\hline \multicolumn{3}{l}{$\begin{array}{l}\text { Runoff curve numbers (CN) values } \\
\text { for AMC II for hydrological soil groups }\end{array}$} \\
\hline Land use/HSG & A & B & C & D \\
Cropland & 59 & 72 & 80 & 84 \\
Built-up land & 58 & 72 & 81 & 86 \\
Tea plantation & 30 & 48 & 65 & 73 \\
Dense forest & 33 & 55 & 70 & 77 \\
Scrub forest & 35 & 58 & 72 & 79 \\
Grassland & 42 & 61 & 86 & 89 \\
Rivers & 98 & 98 & 98 & 98 \\
Sandbar & 77 & 86 & 91 & 94 \\
Wetland & 98 & 98 & 98 & 98 \\
\hline
\end{tabular}

(USDA-SCS curve number 1986)

\section{Results and discussion}

There several methods available for runoff estimation; out of them, the SCS-CN method is one of the most popular and widely accepted empirical models. The main advantage of this model is the incorporation of land-use land cover to estimate runoff. Besides this, SCS-CN method allows to create three antecedent moisture conditions for a region, which is suitable for tropical monsoonal climatic regions as there is monsoonal wet, winter dry, and pre/post monsoonal water recharge seasons, therefore this method selected for runoff estimation in the Panchnoi River basin. Based on integrated variables in SCS-CN model in GIS platform, the annual runoff of the Panchnoi River basin for the period 1990, 2000, and 2015 were 1256 , 1519 , and $1434 \mathrm{~mm}$ respectively. During the concerning periods, the average runoff ratio to rainfall significantly enhanced in the basin caused by LULC dynamics; in the basin, the average runoff ratio for the period 1990, 2000, and 2015 were 63.17, 67.90 , and $71.59 \%$. 


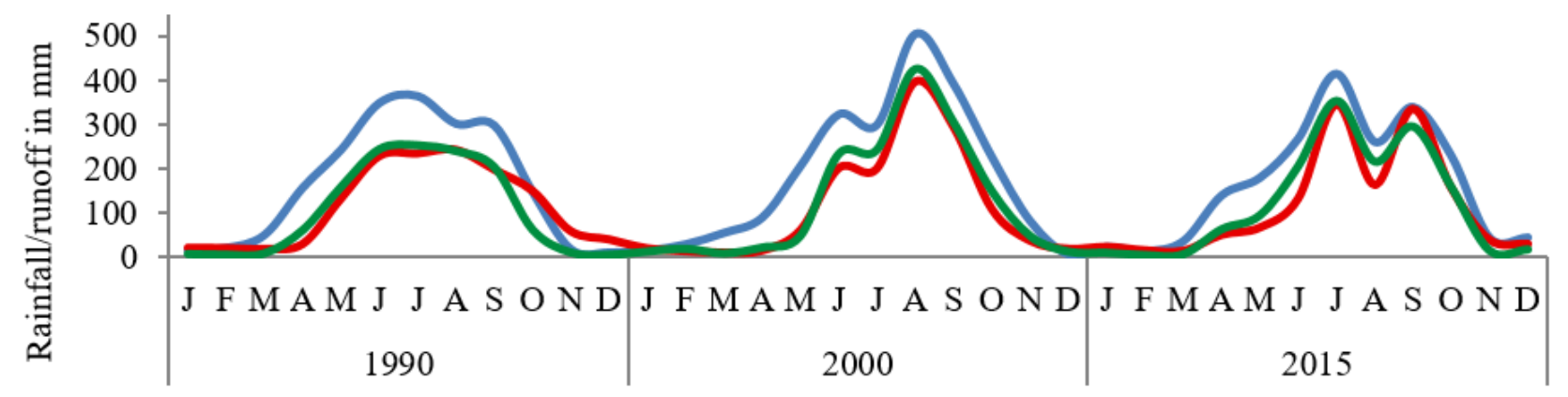

Average basin rainfall $\quad$ Observed Runoff $\quad$ Estimated Runoff

Fig. 5 The comparison among rainfall, observed runoff, and estimated runoff

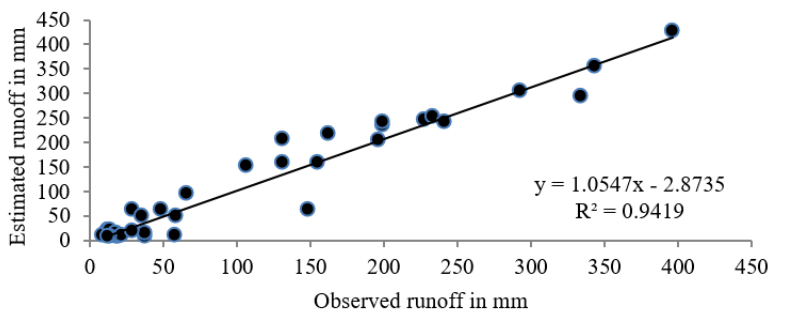

Fig. 6 The relationship between estimated runoff and observed runoff

\subsection{Model validation}

Model validation is an essential parameter to know the reliability of the model in a specific geoenvironmental condition. To check, the reliability of the model in the Panchnoi River basin, the results were verified with observed discharged data of the river, which is collected from Assam water resource department. The collected discharge data in cubic meter per second converted to runoff depth in $\mathrm{mm}$ for making a comparison. Fig. 5 shows that observed runoff almost consolidates with estimated runoff for the years 1990, 2000, and 2015 with minor deviation. Farther, the graph also shows the resemblance of observed and estimated runoff with rainfall during the years. Again in Fig. 6, it is established that the estimated runoff and observed runoff have a high positive correlation. Moreover, a very high $\mathrm{R}^{2}(0.941)$ denotes a close relationship between estimated runoff and observed runoff and both these accurately describe each other; therefore from this, it can validate that the SCS$\mathrm{CN}$ model can estimate runoff in the present geoenvironment conditions.

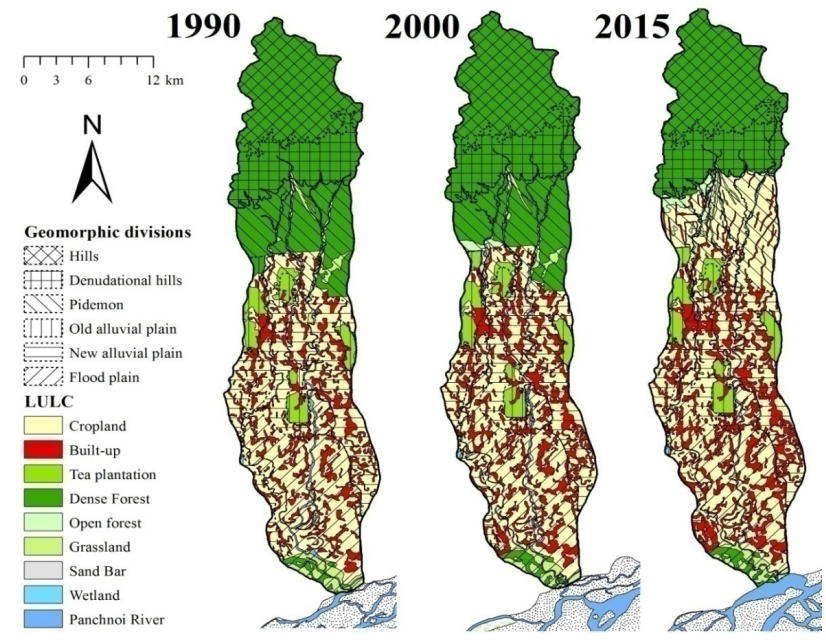

Fig. 7 LULC pattern in the geomorphic zones of the Panchnoi River basin (1990-2015)

\subsection{Impact of LULC dynamics on runoff}

The Panchnoi river basin experiences a massive LULC transformation since 1990. In this study, it observed that area of built-up land increases significantly from 1990 to 2015, whereas the dense forest cover shows a decreasing trend during the tenure (Table 4) in all geomorphic zones except Denudational hills and Hills zone, where thick forest cover remains intact (Fig. 7). Further, the area of cropland shows a decreasing trend in all the geomorphic zones (Flood plain, New alluvial plain and Old alluvial plain) except piedmont zone where it significantly increases during the study period (Table 4). Table 4 clearly shows that Hills and Denudational hills zones remain uninterrupted; whereas the Piedmont zone experiences a high degree of LULC change. The other three zones, i.e. Flood plain, 
Table 4 The pattern of LULC dynamics in the geomorphic zones (1990-2015)

\begin{tabular}{|c|c|c|c|c|c|c|c|}
\hline \multirow{2}{*}{$\begin{array}{l}\text { Geomorphic } \\
\text { zones }\end{array}$} & \multirow{2}{*}{ LULC/ Years } & \multicolumn{3}{|c|}{ Area in $\mathrm{km}^{2}$} & \multicolumn{3}{|c|}{ Area in $\mathrm{km}^{2}$} \\
\hline & & 1990 & 2000 & 2015 & $1990-2000$ & $2000-2015$ & 1990-2015 \\
\hline \multirow{7}{*}{ Flood plain } & Cropland & 89.01 & 83.56 & 81.26 & -5.45 & -2.3 & -7.75 \\
\hline & Built-up land & 28.83 & 34.61 & 38.83 & 5.78 & 4.22 & 10 \\
\hline & Grassland & 9.62 & 7.58 & 7.11 & -2.04 & -0.47 & -2.51 \\
\hline & Sandbar & 1.27 & 3.25 & 1.52 & 1.98 & -1.73 & 0.25 \\
\hline & Dense forest & 3.77 & 4.84 & 5.5 & 1.07 & 0.66 & 1.73 \\
\hline & Rivers & 5.51 & 4.21 & 3.95 & -1.3 & -0.26 & -1.56 \\
\hline & Wetland & 0.26 & 0.22 & 0.1 & -0.04 & -0.12 & -0.16 \\
\hline \multirow{7}{*}{ New alluvial } & Cropland & 90.88 & 84.08 & 79.17 & -6.8 & -4.91 & -11.71 \\
\hline & Built-up land & 34.53 & 41.61 & 48.07 & 7.08 & 6.46 & 13.54 \\
\hline & Tea plantation & 0.44 & 0.5 & 0.46 & 0.06 & -0.04 & 0.02 \\
\hline & Grassland & 0.9 & 0.36 & 0.11 & -0.54 & -0.25 & -0.79 \\
\hline & Sandbar & 0.19 & 1.6 & 0.85 & 1.41 & -0.75 & 0.66 \\
\hline & Rivers & 3.37 & 2.16 & 1.66 & -1.21 & -0.5 & -1.71 \\
\hline & Wetland & 0.7 & 0.27 & 0.26 & -0.43 & -0.01 & -0.44 \\
\hline \multirow{7}{*}{ Old alluvial } & Crop land & 7 & 5.28 & 3.88 & -1.72 & -1.4 & -3.12 \\
\hline & Built-up land & 5.15 & 5.26 & 5.23 & 0.11 & -0.03 & 0.08 \\
\hline & Tea plantation & 20.54 & 23.81 & 25.62 & 3.27 & 1.81 & 5.08 \\
\hline & Sandbar & 0.03 & 0.09 & 0 & 0.06 & -0.09 & -0.03 \\
\hline & Dense forest & 1.88 & 0 & 0 & -1.88 & 0 & -1.88 \\
\hline & Scrub forest & 0.04 & 0.16 & 0 & 0.12 & -0.16 & -0.04 \\
\hline & Rivers & 0.21 & 0.24 & 0.12 & 0.03 & -0.12 & -0.09 \\
\hline \multirow{8}{*}{ Piedmont } & Cropland & 12.12 & 11.02 & 68.08 & -1.1 & 57.06 & 55.96 \\
\hline & Built-up land & 2.87 & 3.51 & 10.4 & 0.64 & 6.89 & 7.53 \\
\hline & Tea plantation & 1.57 & 1.71 & 1.76 & 0.14 & 0.05 & 0.19 \\
\hline & Grassland & 5.76 & 4.49 & 3.16 & -1.27 & -1.33 & -2.6 \\
\hline & Sandbar & 3.11 & 3.9 & 2.49 & 0.79 & -1.41 & -0.62 \\
\hline & Dense forest & 69.21 & 67.87 & 2.07 & -1.34 & -65.8 & -67.14 \\
\hline & Scrub forest & 0.77 & 2.87 & 7.69 & 2.1 & 4.82 & 6.92 \\
\hline & Rivers & 3.35 & 3.38 & 3.11 & 0.03 & -0.27 & -0.24 \\
\hline Denudational hills & Dense forest & 57.52 & 57.52 & 57.52 & 0 & 0 & 0 \\
\hline Hills & Dense forest & 91.43 & 91.43 & 91.43 & 0 & 0 & 0 \\
\hline
\end{tabular}

New alluvial plain and Old alluvial plain mostly covered by human-induced land use (Sanderman et al., 2017; Sugden, 2019) for example cropland, builtup land, and tea plantations; where it observed that cropland mostly converted to built-up land. The alteration of LULC in the geomorphic zones of Panchnoi River basin significantly affects the hydrological processes in the river basin in general and in the geomorphic zones in specific. Therefore it is essential to estimate the amount of accumulated annual runoff of the river basin.


Fig. 8 Runoff dynamics in the Panchnoi River basin (1990-2015) 


\section{Sciendo}

The accumulated surface runoff of the Panchnoi River basin has been calculated for the years 1990, 2000 , and 2015 by using SCS-CN method to evaluate the impact of LULC change on runoff generation in different geomorphic zones. Based on the integrated variables of SCS-CN runoff estimation method in GIS, the annual runoff of the Panchnoi River basin for the years 1990, 2000, and 2015 were estimated; where the average yearly runoff for the respective years estimated at 1 256, 1 519, and $1434 \mathrm{~mm}$ respectively (Fig. 8).

Further, this study it was observed that the area of human-induced land uses constantly increased in all geomorphic zones except the Hills and Denudational hills zones. The transformation of natural land covers to human land uses prominent in the Piedmont zone, where human land uses rose from $16.77 \%$ in 1990 to $81.25 \%$ in 2015 (Table 5). The Flood plain, New alluvial plains and Old alluvial plains zones are saturated with human land-uses, the portion of area cover by this land use pattern were $91.71,76.93 \& 94.10 \%$ respectively in 1990; which increase to $92.92,92.88$, \& $96.93 \%$ in 2015. The area of human land-use (in \%) and natural land covers (in \%) in geomorphic zones computed using the flowing equation:

$$
\begin{array}{r}
\text { Human landuse area }(\text { in } \%)=\left(\frac{(\text { cropland area }+ \text { built up area }+ \text { tea plantation })}{(\text { total unit area })}\right) \cdot 100 \\
\text { Natural land cover }(\text { in } \%)=\left(\frac{(\text { dense forest }+ \text { scrub forest }+ \text { grassland }+ \text { sandbar }+ \text { river }+ \text { wetland })}{(\text { total unit area })}\right) \cdot 100
\end{array}
$$

LULC in most of the geomorphic zones of the Panchnoi River basin notably altered during the study period except in Denudational hills and Hills zone (Fig. 7), although the thickness of dense forest covers in Denudational hills and Hills zones decreased considerably (Jaiswal and Amin, 2020). During the study, it was observed that the runoff ratio in most of the geomorphic zones has significantly increased due to the alteration of natural land covers to human land uses. This phenomenon is most conveniently represented by the Piedmont zone, where about $18 \%$ growth in runoff ratio observed during the study.

The amount of runoff in geomorphic zones is varied base on prevailing LULC. In this study, it was observed that the geomorphic zones which mostly endowed with natural land cover especially with the dense forests (Hills, Denudational hills, and Piedmont) generate comparatively low runoff ratio than the zones endowed with human-induced land uses (Flood plain, New alluvial and Old alluvial plains) (Fig. 8). The transition of LULC dy- namics promotes runoff generation in the basin. Further, this study it was evident that, the geomorphic zones where LULC change was comparatively more, the growth in the runoff generation ratio also more (Table 4, 5 and 6). In the period 1990-2000, the Piedmont zone mostly covered with dense forests, but 2000 afterwards, it was noticed that this dense forests drastically altered to cropland and built-up lands, that leads to increase in runoff ratio, i.e. from $52.82 \%$ (1 $076 \mathrm{~mm}$ ) in 1990, and $58.61 \%(1344 \mathrm{~mm}$ ) in 2000, to $70.46 \%$ (1 467 $\mathrm{mm}$ ) in 2015, although the rainfall decreased from $2293 \mathrm{~mm}$ in 2000 to $2082 \mathrm{~mm}$ in 2015. Despite being decreasing rainfall in this Piedmont zone during this period (from $2293 \mathrm{~mm}$ in 2000 to 2082 $\mathrm{mm}$ in 2015), the growth in runoff ratio is a severe concern to hydrological behaviour in the basin. The Flood plain and New alluvial plain generates higher runoff in the basin as it mostly occupied by human-induced land-uses, i.e. $1444 \mathrm{~mm}(72.72 \%$ of rainfall) and $1360 \mathrm{~mm}$ (71.70\% of rainfall) respectively in 1990, which increase to $1588 \mathrm{~mm}$ (79.20\%)

Table 5 Geomorphic zone wise area of human land-use and natural land covers

\begin{tabular}{lrrrrrr}
\hline \multirow{2}{*}{ Geomorphic zones } & \multicolumn{3}{c}{ Human-induced } & \multicolumn{3}{c}{ Natural } \\
& 1991 & 2001 & 2011 & 1990 & 2000 & 2015 \\
\hline Flood plain & 85.24 & 85.48 & 86.86 & 14.76 & 14.52 & 13.14 \\
New alluvial & 96.06 & 96.64 & 97.79 & 3.94 & 3.36 & 2.21 \\
Old alluvial & 93.8 & 98.59 & 99.66 & 6.2 & 1.41 & 0.34 \\
Piedmont & 16.77 & 16.45 & 81.25 & 83.23 & 83.55 & 18.75 \\
Denudational hills & 0 & 0 & 0 & 100 & 100 & 100 \\
Hills & 0 & 0 & 0 & 100 & 100 & 100 \\
\hline
\end{tabular}


Table 6 Runoff dynamics in the geomorphic divisions of the Panchnoi River basin

\begin{tabular}{lrrrrrrrrr}
\hline Geomorphic & \multicolumn{3}{c}{ Rainfall in $\mathrm{mm}$} & \multicolumn{3}{c}{ Runoff in $\mathrm{mm}$} & \multicolumn{3}{c}{ Runoff ratio to rainfall } \\
division/Year & 1990 & 2000 & 2015 & 1990 & 2000 & 2015 & 1990 & 2000 & 2015 \\
\hline Hills & 2030 & 2308 & 2006 & 1175 & 1402 & 1198 & 57.88 & 60.74 & 59.72 \\
Denudational hills & 2034 & 2299 & 2034 & 1001 & 1210 & 1078 & 49.21 & 52.61 & 52.99 \\
Piedmont & 2037 & 2293 & 2082 & 1076 & 1344 & 1467 & 52.82 & 58.61 & 70.46 \\
Old alluvial plain & 2040 & 2301 & 2102 & 1272 & 1526 & 1404 & 62.35 & 66.31 & 66.79 \\
New alluvial plain & 1986 & 2229 & 2005 & 1444 & 1711 & 1588 & 72.71 & 76.76 & 79.2 \\
Flood plain & 1897 & 2115 & 1915 & 1360 & 1607 & 1507 & 71.7 & 75.98 & 78.69 \\
Total basin area & 1988 & 2237 & 2005 & 1256 & 1519 & 1434 & 63.17 & 67.9 & 71.52 \\
\hline
\end{tabular}

and $1507 \mathrm{~mm}$ (78.69\%) runoff respectively in 2015, due to alteration of cropland to built-up lands.

Further, in this study, it was noticed that the geomorphic zone where the least change in LULC pattern observed, caused nominal growth in runoff ratio. The Old alluvial plain recorded a minor shift in LULC pattern during the period, where most of the alteration observed during 1990-2000 (Table 4 and 5), which resulted in the least increase of runoff ratio, i.e. from $62.35 \%(1272 \mathrm{~mm})$ in 1990 to $66.79 \%(1404 \mathrm{~mm})$ in 2015 (Table 6). Thus the gradual alteration of natural land covers to human land uses has caused an increase in the runoff ratio in the geomorphic zones of the river basin. This study also evident that despite being stagnant forest covers, the forest density in the Hills and Denudational hills has decreased due to illegal lumbering activities caused some growth in runoff ratio.

Increasing runoff in the basin due to LULC change causes a severe threat to environmental sustainability in the basin through soil erosion, sediment yield, and river bed aggradations. Enhanced sediment yield and bed aggradations caused by increased runoff reduce the water carrying capacity of the streams, which ultimately cause severe flood situations along with bank erosion and channel migration in low-lying areas. The findings of the study portrait the impact of LULC change on the runoff phenomenon, which highlights the importance of the formulation of land use management strategies and conservation policies.

\section{Conclusion}

The estimation of surface runoff using the SCS-CN method shows promising results, which was validated through the relationship between observe runoff data and estimated runoff data with high positive co-relation $\left(R^{2}=0.941\right)$ in the Panchnoi River basin. Although, there is deficiency observed in this method as minute variation within particular land use over particular hydrological soil group cannot predict; despite such limitation, this method used worldwide for its accuracy and reliability. The estimation of runoff from the Panchnoi River basin, located at the humid tropical monsoonal climatic regime, reveals the impact of LULU dynamics on runoff phenomenon in different geomorphic divisions through alternating runoff volume. Considering the regional pattern of LULC change according to geomorphic divisions, the study observed the Piedmont zone experience most enormous LULC change and hence a significant increase in runoff ratio observed in the study period, i.e. from $1076 \mathrm{~mm}$ (52.82\% of rainfall) in 1990 to $1467 \mathrm{~mm}(70.46 \%$ of rainfall) in 2015. On the other hand the old alluvial plain zone experience least LULC change, therefore in this zone we observed minor increase in runoff, i.e. from $1272 \mathrm{~mm}$ (62.35\% of rainfall) in 1990 to $1404 \mathrm{~mm}$ (66.79\% of the rainfall) in 2015. In the study, it observed that the geomorphic zones mostly occupied by human land-use always generated high runoff, such as the New alluvial plain and Flood plain. Here in New alluvial zone area of built-up land increases considerably, leads to significant growth in runoff from $1444 \mathrm{~mm}(72.72 \%$ of rainfall) in 1990 to $1588 \mathrm{~mm}$ (79.16\% of rainfall) in 2015. This phenomenon is also similar in flood plain zone where runoff increased from $1360 \mathrm{~mm}$ (71.70\% of rainfall) in 1990 to $1507 \mathrm{~mm}$ (78.59\% of rainfall) in 2015 under the impact of LULC change. The increase of human-induced land use and the decrease of natural land cover in the geomorphic divisions in particular and the Panchnoi River basin, in general, caused the increase in the runoff in the river basin. This enhanced runoff will reduce groundwater recharge rate as a high amount of rainwater drain out $(71.52 \%)$ that will cause serious drinking water problem in dry season shortly. The runoff growth and other allied problems due to change in the land-use pattern should mitigate through social forestry should be encouraged 
to the basin dwellers, and strict regulation should implement to conserve forest lands in the upper part of the basin. Moreover, the conservation of natural forest in their specific locations also helps in maintain runoff volume. The findings of this study can help to formulate land use management strategies for the water and soil conservation practices and the environment.

\section{Acknowledgement}

Authors like to thanks the Centre for Studies in Geography of Dibrugarh University for providing the opportunity to carry out the research study. The authors are thankful for the soil map data provided by the National Bureau of Soil Survey and Land-Use Planning (NBSS\&LUP), India. Furthermore, authors also pay tribute to the India Meteorological Department (IMD) and Water Resource Department, Govt. of Assam for providing meteorological and hydrological data for the study.

\section{References}

Anderson JR, Hardy EE, Roach JT, Witmer RE (1976) A land use and land cover classification system for use with remote sensor data, United States Geological Survey, Geological survey professional paper 964, pp. 8-26. Available at: $<$ https://pubs.usgs.gov/pp/0964/report.pdf>

Askar MH (2014) Rainfall-runoff model using the SCS-CN method and geographic information systems: a case study of Gomal River watershed. WIT Transactions on Ecology and The Environment 178: 159-170.

Bishop MP, James LA, Shroder JF, Walsh SJ (2012) Geospatial technologies and digital geomorphological mapping: Concepts, issues and research. Geomorphology 137: 5-26.

Bosch JM, Hewlett JD (1982) A review of catchment experiments to determine The effect of vegetation changes on water yield and evapotranspiration. Journal of Hydrology 55: 3-23.

Chow VT, Maidment D R, Mays L W (1988) Applied hydrology. McGraw-Hill, New York, U.S.A. Available at: $<$ http://ponce.sdsu.edu/Applied_Hydrology_Chow_1988.pdf>

Cosgrove WJ, Loucks DP (2015) Water management: Current and future challenges and research directions. Water Resources Research 51: 4823-4839.

Dwarakish GS, Ganasri BP (2015) Impact of land-use change on hydrological systems: A review of current modeling approaches. Cogent Geoscience 1(1): 1-15.

Garg V, Nikam BRN, Thakur PK, Aggarwal SP, Gupta PK, Srivastav SK (2018) Human-induced land use land cover change and its impact on hydrology. HydroResearch 1: 48-56.

Geological Survey of India (2009) Geology and mineral resources of Assam. Geological Survey of India, North Eastern Region, Shillong, India.
Geological Survey of India (2010) Geology and mineral resources of Arunachal Pradesh. Geological Survey of India, North Eastern Region, Shillong, India.

Guzha AC, Rufino MC, Okoth S, Jacobs S, Nóbrega RLB (2018) Impacts of land use and land cover change on surface runoff, discharge and low flows: Evidence from East Africa. Journal of Hydrology: Regional Studies 15: 49-67.

Hjelmfelt AT (1991) Investigation of Curve Number procedure. Journal of Hydraulic engineering 117(6): 725-737.

Hibbert AR (1967) Forest treatment effects on water yield. In: Sopper WE, Lull HW (eds) International Symposium for Hydrology. Pergamon, New York, pp. 813

Huda MEA (2019) Estimation of runoff in the high humid foothill areas of Arunachal Himalayas using SCS-CN method. IOSR Journal of Humanities and Social Science 24(6): 20-28.

Jaiswal MK (2013) Geospatial analysis of surface fluvial processes. LAP Lambert Academic Publishing, Saarbrücken.

Jaiswal MK, Thakuria G, Borah AC, Saikia R (2014) Evaluation of parametric impact on soil loss of Panchnoi river basin, NorthEast India, using revised universal soil loss equation (RUSLE). The Clarion- International Multinational Journal 3(1): 51-60.

Jaiswal MK, Amin N (2020) The impact of land use dynamics on the soil erosion in the Panchnoi River basin, Northeastern India. Journal of Geographical Institute "Jovan Cvijić" 70(1): 1-14.

Khare D, Patra D, Mondal A, Kundu S (2017) Impact of landuse/land cover change on runoff in the catchment of a hydro power project. Applied Water Science 7: 787-800.

Li P, Li H, Yang G, Zhang Q, Diao Y (2018) Assessing the hydrologic impacts of land use change in the Taihu Lake Basin of China from 1985 to 2010. Water 10(11): 1512.

Loucks DP, Beek EV (2017) Water resource systems planning and management - An introduction to methods, models, and applications. Springer Nature, Cham, pp. 1-42.

Ma K, Huang X, Guo B, Wang Y, Gao L (2018) Land use/land cover changes and Its response to hydrological characteristics in the upper reaches of Minjiang River. Proceeding of the International Association of Hydrological Sciences 379: 243-248.

Matomela N, Tianxin L, Morahanye L, Bishoge OK, Ikhumhen HO (2019) Rainfall-runoff estimation of Bojiang lake watershed using SCS-CN model coupled with GIS for watershed management. Journal of Applied and Advanced Research 4(1): 16-24.

Messele TA, Moti DT (2019) Modeling change of land use on hydrological response of river by remedial measures using Arc SWAT: Case of Weib Catchment, Ethiopia. International Journal of Innovative Technology and Exploring Engineering 8(11): 2381-2390.

Mishra S K, Singh V P (2003) Soil Conservation Service Curve Number (SCS-CN) Methodology. Water Science and Technology Library 42: 84-146.

Ningaraju HJ, Kumar SBG, Surendra HJ (2016) Estimation of runoff using SCS-CN and GIS method in ungauged watershed: a case study of Kharadya mill watershed, India. International Journal of Advanced Engineering Research and Science 3(5): $36-42$

NRSA (2006) Manual of national land use/land cover mapping using multi-temporal satellite data. National Remote Sensing Agency, Departmentnt of Space, Govt. of India. Hyderabad, pp. $18-56$.

Odiji CA, Aderoju OM, Ekwe MC, Oje DT, Imhanfidon JO (2020) Surface runoff estimation in an upper watershed using geospatial based soil conservation service - Curve Number method. Global Journal of Environmental Science and Management 6(3): $415-428$. 


\section{S sciendo}

Rawat KS, Singh SK (2017) Estimation of surface run-off from semi-arid ungauged agricultural watershed using SCS-CN method and Earth observation data sets. Water Conservation Science and Engineering 1: 233-247.

Russo T, Alfredo K, Fisher J (2014) Sustainable water management in urban, agricultural, and natural systems. Water 6(12): 3934-3956.

Satheeshkumar S, Venkateswaran S, Kannan R (2017) Rainfall-runoff estimation using SCS-CN and GIS approach in the Pappiredipatti watershed of the Vaniyar sub basin, South India. Modeling Earth Systems and Environment 3(24).

Samie M, Ghazavi R, Vali A, Pakparvar M (2019) Evaluation of the effect of land use change on runoff using supervised classified satellite data. Global NEST Journal 21(2): 245-252.

Sanderman J, Hengl T, Fiske G J (2017) Soil carbon debt of 12,000 years of human land use. PNAS 114(36): 9575-9580.

Sharpley AN, Williams JR (1976) EPIC - Erosion Productivity Impact Calculator: Model Documentation (USDA Technical Bulletin Number 1768). Department of Agriculture, Washington DC.

Sugden AM (2019) A synthetic history of human land use. Science 365(6456): 865-878.

Sutradhar H (2018) Surface runoff estimation Using SCS-CN method in Siddheswari River Basin, Eastern India. Journal of Geography, Environment and Earth Science International 17(2): 1-9.

Tailor D, Shrimali NJ (2016) Surface runoff estimation by SCS Curve Number method using GIS for Rupen-Khan watershed, Mehsana district, Gujarat. Journal of Indian water resource society, 36(4): 1-5.

Uwizeyimana D, Mureithi SM, Mvuyekure SM, Karuku G, Kironchi G (2018) Modelling surface runoff using the soil conservation service - Curve Number method in a drought prone agro-ecological zone in Rwanda. International Soil and Water Conservation Research 7(1): 9-17.
United States Department of Agriculture (1964) Hydrology. In: National Engineering Handbook, Soil Conservation Service (Supplement A, Section 4, Chap. 10). Soil Conservation Service, USDA, Washington DC.

United States Department of Agriculture (1972) A method for estimating volume and rate orun-offff in small watersheds. SCS technical paper-149, Soil Conservation Service, USDA, Washington DC.

United States Department of Agriculture (1986) Urban hydrology for small watersheds. Technical Release No. 55 (Second Edition). Soil Conservation Service, USDA, Washington DC.

United States Department of Agriculture (2004) Estimation of direct runoff from storm rainfall hydrology. National Engineering Handbook, Part 630. Soil Conservation Service, USDA, Washington DC.

Venkatesh K, Ramesh H (2018) Impact of land use land cover change on run off generation in Tungabhadra River basin. ISPRS Annals of the Photogrammetry, Remote Sensing and Spatial Information Sciences, 4(5): 367-374.

Yin J, He F, Xiong Y J, Qiu GY (2017) Effects of land use/land cover and climate changes on surface runoff in a semi-humid and semiarid transition zone in northwest China. Hydrology and Earth System Sciences 21: 183-196.

Zare M, Samani AAN, Mohammady M (2016) The impact of land use change on runoff generation in an urbanising watershed in the north of Iran. Environmental Earth Sciences 75: 1279.

Zelelew DG (2017) Spatial mapping and testing the applicability of the Curve Number method for ungauged catchments in Northern Ethiopia. International Soil and Water Conservation Research 5(4): 293-301.

Zhang L, Nan Z, Xu Y, Li S (2016) Hydrological impacts of land use change and climate variability in the headwater region of the Heihe River Basin, Northwest China. PLoS ONE 11(6): $1-25$. 